\title{
Association between Tumor necrosis factor-alpha gene polymorphisms and prostate cancer risk: a meta-analysis
}

\author{
Liping $\mathrm{Ma}^{\dagger}$, Jiangyang Zhao ${ }^{\dagger}$, Taijie Li, Yu He, Jian Wang, Li Xie, Xue Qin ${ }^{*}$ and Shan Li ${ }^{*}$
}

\begin{abstract}
Background: Tumor necrosis factor-alpha (TNF-a) is an important inflammatory cytokine that may play a role in controlling the progression of prostate cancer. Two common polymorphisms in the TNF-a gene, $-308 \mathrm{G} / \mathrm{A}$ and $-238 \mathrm{C} / T$, have been suggested to alter the risk for prostate cancer, but the results have been inconclusive so far. In order to obtain a better understanding of the effects of these two polymorphisms on prostate cancer risk, all available studies were considered in a meta-analysis.

Methods: We conducted a comprehensive literature search in the Cochrane Library, PubMed, EMBASE, Chinese Biomedical Literature database (CBM), and the China National Knowledge Infrastructure (CNKI). The associations were evaluated by calculating the pooled odds ratio (OR) with 95\% confidence interval (95\% CI).

Results: In this meta-analysis, we included 14 studies with 5,757 patients and 6,137 control subjects for the TNF-a-308G/A polymorphism and 1,967 patients and 2,004 control subjects for the TNF-a-238C/T polymorphism. A significantly increased prostate cancer risk was found to be associated with the TNF-a-308C/T polymorphism in studies with healthy volunteers ( $A A+A G$ vs. $G G: O R=1.531,95 \% C l=1.093-2.145 ; P=0.013 ; A G$ vs. $G G: O R=1.477,95 \% C l=1.047-2.085 ; P=0.026$ ). No significant association was found between the TNF-a-238G/A polymorphism and prostate cancer risk in the overall or subgroup analyses. There was no risk of publication bias in this meta-analysis.
\end{abstract}

Conclusions: Our results suggest that while the TNF-a-238G/A polymorphism may not be associated with prostate cancer the TNF-a-308C/T polymorphism may significantly contribute to prostate cancer susceptibility in healthy volunteers.

Virtual slides: The virtual slide(s) for this article can be found here: http://www.diagnosticpathology.diagnomx.eu/ vs/1629288120116301

Keywords: Tumor necrosis factor- alpha, Prostate cancer, Meta-analysis, Polymorphism

\section{Introduction}

Prostate cancer is the most common malignant tumour of the male reproductive system in the Western hemisphere. Approximately 238,590 new cases and 29,270 deaths of prostate cancer are reported annually [1]. Therefore, it is critically important to clarify the mechanism of its carcinogenesis, so that prostate cancer can be detected at an early stage. Polygenic and external environmental factors are known or suspected to be risk

\footnotetext{
*Correspondence: qinxue919@126.com; lis8858@126.com

${ }^{\dagger}$ Equal contributors

Department of Clinical Laboratory, First Affiliated Hospital of Guangxi Medical University, Nanning, Guangxi Zhuang Autonomous Region 530021, China
}

factors for prostate cancer [2-4]. Specifically, genetic factors may contribute as much as $42 \%$ to the risk of prostate cancer [5]. Recently, cytokine genetic polymorphisms were found to be related associated with increased inflammation, increased cytokine production, and possibly increased prostate cancer risk [6].

Tumour necrosis factor-alpha (TNF- $\alpha$ ) is a mediator of the inflammatory process that is secreted by monocytes, macrophages, neutrophils, T cells, and NK cells after stimulation. TNF- $\alpha$ is a pro-inflammatory molecule that may play an important role in the development of the immune response $[7,8]$ and affect the progression of prostate cancer [9]. The TNF- $\alpha$ gene is located in the 
major histocompatibility complex III region on chromosome 6p21.3. In recent years, several common single nucleotide polymorphisms (SNPs) have been identified in the TNF- $\alpha$ promoter regions, which can regulate the expression level of TNF- $\alpha$, such as TNF- $\alpha-308$ G/A (rs1800629) and TNF- $\alpha-238 \mathrm{C} / \mathrm{T}$ (rs361525) [10,11]. TNF- $\alpha 308 \mathrm{G} / \mathrm{A}$ is a $\mathrm{G}$ to $\mathrm{A}$ transition at nucleotide position 308 in the promoter region of the gene, and TNF$\alpha-238 \mathrm{G} / \mathrm{A}$ is a $\mathrm{G}$ to $\mathrm{A}$ transition at nucleotide position 238 in the promoter region of the gene. Previous data have shown that polymorphisms of TNF- $\alpha$ at positions 308 and 238 (TNF2 and TNFA alleles, respectively) are associated with increased release of TNF- $\alpha[6,12,13]$. Therefore, TNF- $\alpha$ polymorphism may be related to prostate cancer risk. Thus, it is biologically reasonable to hypothesize a potential relationship between TNF- $\alpha$ polymorphisms and prostate cancer risk.

A number of studies have reported the association between prostate cancer risk and TNF- $\alpha$ promoter polymorphisms -308G/A and/ or -238G/A polymorphisms, but the results are controversial [14-16]. A single study may not have sufficient power to completely demonstrate this complicated genetic relationship because of relatively small sample sizes, which have low statistical power. Larger studies could overcome these disadvantages. With respect to the TNF- $\alpha$-308G/A polymorphism, Wang et al. [17] conducted a meta-analysis in 2011 and found that this polymorphism was not associated with susceptibility to prostate cancer. However, that meta-analysis only included six eligible studies and several new studies with more data have been published since 2011; thus, that meta-analysis may not be comprehensive and may cause some bias to the final result. To the best of our knowledge, no meta-analyses investigating the TNF- $\alpha$-238G/A polymorphism have ever been published. Therefore, to generate a more valuable conclusion on the association between TNF- $\alpha$ polymorphisms and prostate cancer risk, we performed a metaanalysis of all eligible case-control studies investigating the association between the $-308 \mathrm{G} / \mathrm{A}$ and $-238 \mathrm{G} / \mathrm{A}$ polymorphisms of the TNF- $\alpha$ gene and prostate cancer risk.

\section{Methods}

\section{Search strategy}

We conducted a comprehensive literature search in the Cochrane Library, PubMed, EMBASE, Chinese Biomedical Literature database (CBM), and the China National Knowledge Infrastructure (CNKI) using the search terms "prostate cancer OR prostate carcinoma OR PCa", "polymorphism or variant OR mutation OR genotype" and "Tumour Necrosis Factor-alpha OR TNF OR TNF- $\alpha$ " and various combinations of these terms. All the articles were updated on September 10, 2013. The search was performed without any limitations of language. Review articles, original articles, and other studies of interest were examined to identify additional eligible studies.

\section{Selection criteria}

Studies included in the meta-analysis were required to meet the following criteria: (1) studies investigating the association between TNF- $\alpha$ gene polymorphisms and prostate cancer risk; (2) case-control or cohort studies; and (3) the papers must list the sample size, distribution of genotype, and allele frequency. If serial studies of the same population from the same group were reported, the most recent or largest population was chosen. When a study reported the results on different subpopulations, we treated it as separate studies in the meta-analysis. Studies were excluded from our meta-analysis if they met one of the following exclusion criteria: (1) the study was conducted on animals, (2) the design was based on family or sibling pairs, or (3) insufficient original data was available for data extraction, for instance, the number of genotypes could not be ascertained.

\section{Data extraction}

$\mathrm{T}$ Two separate investigators (Ma and Zhao) reviewed and extracted data from the studies included independently to ensure the accuracy of the data. The following parameters were collected from eligible studies: first author's surname, year of publication, country of study population, ethnicity, genotyping methods, sample size, source of controls (hospital-based, population-based, or healthy volunteers), matching variables, prostate cancer diagnosis, QC when genotyping, and the number of genotype frequencies in cases and controls. The two investigators verified data accuracy by comparing collection forms between investigators. If different results were generated, they would carry out discussions until a consensus was reached.

\section{Quality score assessment}

The quality of the selected studies was independently evaluated by two reviewers (Ma, and Zhao). The criteria for quality appraisal are listed in Table 1. The quality scoring system was originally proposed by Thakkinstian et al. [18]. Scores ranged from the lowest value 0 to the highest value 14, with higher scores indicating better quality. Disagreements were resolved by consensus.

\section{Statistical analysis}

Crude odds ratios (ORs) and corresponding 95\% confidence intervals (CIs) were employed to estimate the strength of association between the two polymorphisms and prostate cancer risk. The recessive genetic model, dominant genetic model and additive genetic models were used to calculate the pooled ORs and 95\% CIs for 


\section{Table 1 Scale for quality assessment}

\begin{tabular}{|c|c|}
\hline Criteria & Score \\
\hline \multicolumn{2}{|l|}{ 1. Representativeness of cases } \\
\hline Selected from population or cancer registry & 3 \\
\hline Selected from hospital & 2 \\
\hline $\begin{array}{l}\text { Selected from pathology archives, but without clearly defined } \\
\text { sampling frame or with extensive inclusion/exclusion criteria }\end{array}$ & 1 \\
\hline Not described & 0 \\
\hline \multicolumn{2}{|l|}{ 2. Source of controls } \\
\hline Population- based & 3 \\
\hline Blood donors or volunteers & 2 \\
\hline Hospital-based (cancer -free patients) & 1 \\
\hline Not described & 0 \\
\hline \multicolumn{2}{|l|}{ 3. Pecimens of cases determining genotypes } \\
\hline White blood cells or normal tissues & 1 \\
\hline Tumor tissues or exfoliated cells of tissue & 0 \\
\hline \multicolumn{2}{|l|}{ 4. Ascertainment of prostate cancer } \\
\hline Histopathologic confirmation & 2 \\
\hline Diagnosis of prostate cancer by patient medical record & 1 \\
\hline Not described & 0 \\
\hline \multicolumn{2}{|l|}{ 5. Total sample size } \\
\hline$\geqq 1000$ & 3 \\
\hline$\geqq 400$ but $<1000$ & 2 \\
\hline$\geqq 200$ but $<400$ & 1 \\
\hline$<200$ & 0 \\
\hline \multicolumn{2}{|l|}{ 6. Hardy-Weinbe rg equilibrium in controls } \\
\hline Hardy-Wei nberg equilibrium & 1 \\
\hline Hardy-Wei nberg disequilibrium & 0 \\
\hline \multicolumn{2}{|l|}{ 7. Quality control of genotyping methods } \\
\hline Repetition of partial/total tested samples & 1 \\
\hline Not described 0 & 0 \\
\hline
\end{tabular}

both the polymorphisms. Heterogeneity among the studies included in the meta-analysis was evaluated by the chi-square-based $\mathrm{Q}$ test and quantified by the $\mathrm{I}^{2}$ metric. $\mathrm{I}^{2}$ values of $75 \%, 50 \%$, and $25 \%$ were considered to reflect high, moderate, and low heterogeneity, respectively [19]. When no statistical heterogeneity was found $\left(\mathrm{I}^{2}<\right.$ $50 \%$ or $\mathrm{P}>0.10$ ), the ORs and $95 \%$ CI would be estimated for each study in the fixed-effect model (MantelHaenszel method) [20]. Otherwise, the random-effect model (DerSimonian and Laird method) was applied [21]. Logistic meta-regression and subgroup analyses were performed to explore possible explanations for heterogeneity among studies. The following characteristics of participants were included as covariates in the metaregression analysis: source of controls, ethnicity, genotyping methods, quality score, $\mathrm{QC}$ when genotyping, and prostate cancer diagnosis. Subgroup analyses were performed by ethnic group and source of controls. In addition, Galbraith plots analysis was performed for further exploration of heterogeneity.

A funnel plot was used to verify potential publication bias using the standard error of log (OR) for each publication plotted against its $\log (\mathrm{OR})$, and the asymmetry of the funnel plot was tested by Egger's regression [22]. The $t$ test was used to determine the significance of the asymmetry, and if the $\mathrm{P}$ value was $<0.10$, indicating the presence of publication bias, the non-parametric "trim and fill" method was used to adjust for it [23]. Sensitivity analysis was conducted to validate the credibility of outcomes in this meta-analysis. It was carried out by sequential omission of individual studies or by omitting studies without high quality. The Hardy-Weinberg equilibrium (HWE) in the controls was evaluated in our meta-analysis using the goodness-of-fit chi-square test, and $\mathrm{p}<0.05$ was considered representative of a departure from HWE. Statistical tests were performed using the program STATA 12.0 software (Stata-Corp LP, College Station, TX). All statistical tests were two-sided.

\section{Results}

\section{Study characteristics}

As shown in Figure 1, a total of 79 published records found on Cochrane Library, PubMed, EMBASE, CBM, and CNKI were identified as having met the search criteria. After the titles and abstracts were reviewed, 66 of these articles were excluded: 46 were not related to gene polymorphisms, 17 articles discussed polymorphisms other than $-308 \mathrm{G} / \mathrm{A}$ and/or $-238 \mathrm{G} / \mathrm{A}$ of TNF- $\alpha, 1$ was not closely relevant to prostate cancer, and 2 were metaanalyses $[17,24]$. Manual search of references cited in the published studies did not reveal any more relevant articles. These 13 full-text articles were then subjected to further examination, and 1 article was further excluded as it discussed the TNF- $\alpha$ gene and prognosis. Thus, a total of 12 records with a case-control design met the inclusion criteria for the meta-analysis (Figure 1). Of these, two articles contained two different subpopulations and were treated as two independent studies. The corresponding characteristics are presented in Table 2 . Twelve articles [14-16,25-33] with 14 studies (5,757 cases and 6,137 controls) discussed TNF- $\alpha$-308G/A polymorphism, while $4 \cdot[15,16,30,31]$ articles containing 5 studies (1,967 cases and 2,004 controls) discussed TNF- $\alpha-238 \mathrm{G} / \mathrm{A}$ polymorphism. The number of cases in these studies varied from 96 to 2,225 , and the number of controls varied from 126 to 2,251. Of all the eligible studies for TNF- $\alpha$-308G/A polymorphism, seven were performed in Caucasians populations; four, in Asians; two, in mixed populations (White and other); and one, in an African-American population. Similarly for TNF$\alpha$-238G/A polymorphism, three were performed in 


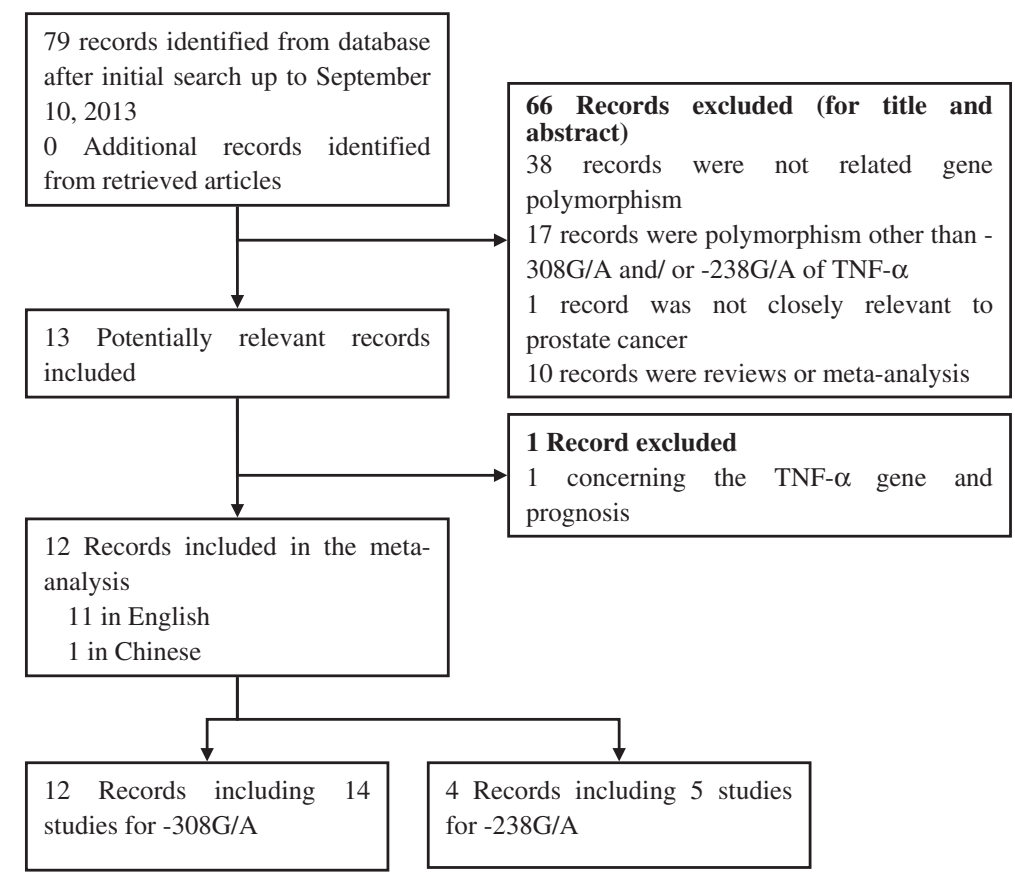

Figure 1 Flow diagram of included studies for this meta-analysis.

Caucasians and two in non-Caucasians. Genotyping was performed using polymerase chain reaction-restriction fragment length polymorphism (PCR-RFLP), amplification refractory mutation system-PCR (ARMS-PCR), TaqMan assay, and polymerase chain reaction (PCR) analyses on genomic DNA. For the TNF- $\alpha-308 \mathrm{G} / \mathrm{A}$ polymorphism, the genotype distributions in the control groups of all but one study were in agreement with the HWE [33]. Similarly, for the TNF- $\alpha-238 \mathrm{G} / \mathrm{A}$ polymorphism, the genotype distributions in the control group of one study [30] was not consistent with the HWE.

\section{Results of the meta-analysis}

The data suggested no significant association between the TNF- $\alpha-308$ G/A polymorphism and prostate cancer risk in all genetic models (additive genetic models: AA vs. GG and AG vs. GG, recessive genetic model: AA vs. AG + GG, and dominant genetic model: AA + AG vs. GG; Table 3, Figure 2) in the overall populations. Additional subgroup analyses stratified by ethnicity revealed no association between TNF- $\alpha$-308G/A polymorphism and prostate cancer risk in any of the genetic models. When stratified by source of controls, a significantly increased prostate cancer risk was found among healthy volunteer studies in the additive model AG vs. GG $(\mathrm{OR}=1.477,95 \% \mathrm{CI}=1.047-$ $2.085, \mathrm{P}=0.026, \mathrm{I}^{2}=0.0 \%$, and $\mathrm{P}_{\mathrm{Q}}=0.602$ for heterogeneity) and dominant model AA + AG vs. GG (OR = 1.531, $95 \% \mathrm{CI}=1.093-2.145, \mathrm{P}=0.013, \mathrm{I}^{2}=0.0 \%$, and $\mathrm{P}_{\mathrm{Q}}=0.628$ for heterogeneity) but not in the recessive model AA vs. $\mathrm{AG}+\mathrm{GG}(\mathrm{OR}=2.65,95 \% \mathrm{CI}=0.679-10.341, \quad \mathrm{P}=0.161$,
$\mathrm{I}^{2}=0.0 \%$, and $\mathrm{P}_{\mathrm{Q}}=0.997$ for heterogeneity). Furthermore, excluding the studies by $\mathrm{OH}$ et al. [16] and Sáenz-López et al. [14], which were shown as outliers in our Galbraith plot analysis, did not influence the significance of the summary ORs for the TNF- $\alpha$-308G/A polymorphism in different comparison models in the overall population and subgroup analyses.

Data from five case-control studies comprising 1,967 prostate cancer cases and 2,004 controls were pooled for the analysis of the TNF- $\alpha-238 \mathrm{G} / \mathrm{A}$ polymorphism. No association was detected between TNF- $\alpha$-238G/A polymorphism and prostate cancer risk in all genetic models in the overall population. Similarly, in the subgroup analysis by source of controls and ethnicity, no significant association was found (Table 3).

\section{Heterogeneity analysis}

For the TNF-a-308G/A polymorphism, substantial heterogeneities between studies were observed in the additive and dominant models ( $\mathrm{p}<0.001$ in both models) in the overall populations. We further employed meta-regression and subgroup analyses to explore the source of heterogeneity. However, meta-regression analysis of data showed that ethnicity, genotyping methods, source of controls, QC when genotyping, prostatic cancer diagnosis, and quality scores did not affect modifiers. Subsequently, we stratified the studies by ethnicity and source of controls, and observed the lack of homogeneity among Caucasians and hospital-based studies in the two genetic models (Table 3). 
Table 2 Characteristics of eligible studies in this meta-analysis

\begin{tabular}{|c|c|c|c|c|c|c|c|c|c|c|c|c|}
\hline \multirow[t]{2}{*}{ First author (year) } & \multirow[t]{2}{*}{ Country } & \multirow[t]{2}{*}{ Ethnicity } & \multirow{2}{*}{$\begin{array}{l}\text { Genotyping } \\
\text { methods }\end{array}$} & \multirow{2}{*}{$\begin{array}{l}\text { Source of } \\
\text { controls }\end{array}$} & \multirow{2}{*}{$\begin{array}{l}\text { Sample size } \\
\text { (case/control) }\end{array}$} & \multirow{2}{*}{$\begin{array}{l}\text { Matching } \\
\text { variables }\end{array}$} & \multirow{2}{*}{$\begin{array}{l}\text { Prostate cancer } \\
\text { diagnosis }\end{array}$} & \multirow{2}{*}{$\begin{array}{l}\text { QC when } \\
\text { genotyping }\end{array}$} & \multirow{2}{*}{ PI } & \multicolumn{2}{|c|}{ HWE (P value) } & \multirow{2}{*}{$\begin{array}{l}\text { Quality } \\
\text { scores }\end{array}$} \\
\hline & & & & & & & & & & $-308 \mathrm{G} / \mathrm{A}$ & $-238 \mathrm{G} / \mathrm{A}$ & \\
\hline Ribeiro (2012) & Portugal & Caucasia & TaqMan & HB & $449 / 557$ & Age & $\mathrm{HC}$ & No & $-308 \mathrm{G} / \mathrm{A}$ & 0.155 & - & 10 \\
\hline Berhane (2012) & India (N) & Asia & ARMS-PCR & $H B$ & $150 / 150$ & Age & $\mathrm{HC}$ & No & $-308 \mathrm{G} / \mathrm{A}$ & 0.662 & - & 10 \\
\hline Wang (2009) & America $(W)$ & mixed & TaqMan & PB & $251 / 250$ & Age, sex,ethnicity & $\mathrm{HC}$ & No & $-308 \mathrm{G} / \mathrm{A}$ & 0.529 & - & 12 \\
\hline Moore (2009) & Finland (W) & mixed & TaqMan & PB & $949 / 857$ & Age, sex & $\mathrm{HC}$ & Yes & $-308 \mathrm{G} / \mathrm{A}$ & 0.231 & - & 14 \\
\hline Kesarwani (2009) & India (E) & Asia & PCR-RFLP & PB & 197/256 & Age, sex, ethnicity & $\mathrm{HC}$ & Yes & $-308 \mathrm{G} / \mathrm{A}$ & 0.115 & - & 13 \\
\hline Zabaleta 1 (2008) & America $(W)$ & Caucasia & TaqMan & $\mathrm{HB}$ & $950 / 785$ & Ethnicity & $\mathrm{HC}$ & Yes & $-308 \mathrm{G} / \mathrm{A},-238 \mathrm{G} / \mathrm{A}$ & 0.505 & 0.295 & 10 \\
\hline Zabaleta 2 (2008) & America (W) & African-American & TaqMan & $\mathrm{HB}$ & $131 / 256$ & Ethnicity & $\mathrm{HC}$ & Yes & $-308 \mathrm{G} / \mathrm{A},-239 \mathrm{G} / \mathrm{A}$ & 0.959 & 0.006 & 8 \\
\hline Sáenz-López (2008) & Spain & Caucasia & TaqMa & $\mathrm{HV}$ & $296 / 310$ & Ethnicity & $\mathrm{HC}$ & No & $-308 \mathrm{G} / \mathrm{A}$ & 0.715 & - & 9 \\
\hline Danforth 1 (2008) & America $(W)$ & Caucasia & TaqMan & PB & $1155 / 1389$ & Age & $\mathrm{HC}$ & Yes & $-308 \mathrm{G} / \mathrm{A}$ & 0.795 & - & 14 \\
\hline Danforth 2 (2008) & America (W) & Caucasia & TaqMan & PB & $2225 / 2251$ & Age & $\mathrm{HC}$ & Yes & $-308 \mathrm{G} / \mathrm{A},-239 \mathrm{G} / \mathrm{A}$ & 0.217 & 0.737 & 14 \\
\hline Ge (2007) & China & Asia & TaqMan & $\mathrm{HB}$ & $490 / 490$ & Age & $\mathrm{HC}+\mathrm{PC}$ & No & $-308 \mathrm{G} / \mathrm{A}$ & 0.609 & 0.462 & 11 \\
\hline Wu (2004) & China & Asia & PCR & HV & $96 / 126$ & Sex & $\mathrm{HC}$ & No & $-308 \mathrm{G} / \mathrm{A},-239 \mathrm{G} / \mathrm{A}$ & 0.883 & - & 7 \\
\hline McCarron (2002) & UK & Caucasia & $P C R$ & HB & 239/220 & Ethnicity & $\mathrm{HC}$ & No & $-308 \mathrm{G} / \mathrm{A}$ & 0.023 & - & 7 \\
\hline $\mathrm{OH}(2000)$ & America & Caucasia & PCR & HB & $146 / 244$ & Ethnicity & PC & Yes & $-308 \mathrm{G} / \mathrm{A},-239 \mathrm{G} / \mathrm{A}$ & 0.554 & 0.091 & 9 \\
\hline
\end{tabular}

PI, Polymorphism(s) investigated; QC, Quality control; NA, Not available; PB, Population-based; HB, Hospital-based; HV, healthy-volunteers; HC, Histologically confirmed; PC, Pathologically confirmed; HWE, Hardy-Weinberg equilibrium in control population. 
Table 3 Meta-analysis of the TNF-a gene polymorphisms on prostate cancer risk

\begin{tabular}{|c|c|c|c|c|c|c|c|c|c|}
\hline \multirow[t]{2}{*}{ Comparison } & \multirow[t]{2}{*}{ Population } & \multirow[t]{2}{*}{ No. of studies } & \multicolumn{3}{|c|}{ Test of association } & \multirow[b]{2}{*}{ model } & \multicolumn{3}{|c|}{ Test of heterogeneity } \\
\hline & & & $\mathrm{OR}$ & $95 \% \mathrm{Cl}$ & $P$ value & & $\mathrm{X} 2$ & $12(\%)$ & $P$ value \\
\hline \multicolumn{10}{|l|}{ TNF-a-308G/A } \\
\hline \multirow[t]{8}{*}{ AA vs. GG } & Overall & 14 & 0.936 & $0.733-1.195$ & 0.595 & $\mathrm{~F}$ & 16.20 & 19.8 & 0.238 \\
\hline & Caucasia & 8 & 0.762 & $0.569-1.021$ & 0.068 & $\mathrm{~F}$ & 5.68 & 0.0 & 0.461 \\
\hline & Asia & 3 & 1.558 & $0.620-3.419$ & 0.346 & $\mathrm{~F}$ & 4.29 & 30.1 & 0.231 \\
\hline & Mix & 2 & 1.616 & $0.917-2.848$ & 0.097 & $\mathrm{~F}$ & 0.11 & 0.0 & 0.736 \\
\hline & African-American & 1 & 1.119 & $0.181-6.903$ & 0.904 & - & - & - & - \\
\hline & PB & 5 & 0.886 & $0.660-1.190$ & 0.422 & $\mathrm{~F}$ & 6.72 & 40.5 & 0.152 \\
\hline & $\mathrm{HB}$ & 7 & 0.924 & $0.557-1.481$ & 0.743 & $\mathrm{~F}$ & 6.76 & 11.2 & 0.344 \\
\hline & $\mathrm{HV}$ & 2 & 2.861 & $0.732-11.181$ & 0.131 & $F$ & 0.00 & 0.0 & 0.979 \\
\hline \multirow[t]{8}{*}{ AG vs. GG } & Overall & 14 & 1.105 & $0.932-1.309$ & 0.251 & $\mathrm{R}$ & 41.38 & 68.6 & $<0.001$ \\
\hline & Caucasia & 7 & 1.234 & $0.965-1.600$ & 0.092 & $\mathrm{R}$ & 31.63 & 81.0 & $<0.001$ \\
\hline & Asia & 4 & 0.928 & $0.699-1.234$ & 0.608 & $\mathrm{~F}$ & 4.12 & 27.2 & 0.249 \\
\hline & Mix & 2 & 1.065 & $0.882-1.288$ & 0.512 & $\mathrm{~F}$ & 0.70 & 0.0 & 0.404 \\
\hline & African-American & 1 & 0.458 & $0.204-1.027$ & 0.058 & - & - & - & - \\
\hline & PB & 5 & 0.997 & 0.899-1.106 & 0.958 & F & 3.39 & 0.0 & 0.495 \\
\hline & $\mathrm{HB}$ & 7 & 1.174 & $0.709-1.746$ & 0.428 & $\mathrm{R}$ & 32.78 & 81.7 & $<0.001$ \\
\hline & $\mathrm{HV}$ & 2 & 1.477 & $1.047-2.085$ & 0.026 & $F$ & 0.27 & 0.0 & 0.602 \\
\hline \multirow[t]{8}{*}{$A A+A G$ vs. GG } & Overall & 14 & 1.103 & $0.932-1.306$ & 0.254 & $\mathrm{R}$ & 43.71 & 70.3 & $<0.001$ \\
\hline & Caucasia & 8 & 1.206 & $0.941-1.545$ & 0.138 & $\mathrm{R}$ & 32.21 & 81.4 & $<0.001$ \\
\hline & Asia & 3 & 1.008 & $0.657-1.547$ & 0.97 & $\mathrm{R}$ & 6.83 & 56.1 & 0.078 \\
\hline & Mix & 2 & 1.101 & $0.916-1.323$ & 0.304 & $\mathrm{~F}$ & 0.63 & 0.0 & 0.429 \\
\hline & African-American & 1 & 0.513 & $0.242-1.088$ & 0.082 & - & - & - & - \\
\hline & PB & 5 & 0.987 & $0.892-1.091$ & 0.799 & $\mathrm{~F}$ & 4.96 & 19.4 & 0.291 \\
\hline & $\mathrm{HB}$ & 7 & 1.174 & $0.803-1.719$ & 0.408 & $\mathrm{R}$ & 32.22 & 81.4 & $<0.001$ \\
\hline & $\mathrm{HV}$ & 2 & 1.531 & $1.093-2.145$ & 0.013 & $\mathrm{~F}$ & 0.24 & 0.0 & 0.628 \\
\hline \multirow[t]{8}{*}{$A A$ vs. $G G+A G$} & Overall & 14 & 0.92 & $0.721-1.172$ & 0.502 & $F$ & 16.2 & 19.7 & 0.239 \\
\hline & Caucasia & 7 & 0.748 & $0.559-1.001$ & 0.051 & F & 5.93 & 0.0 & 0.431 \\
\hline & Asia & 4 & 1.559 & $0.618-3.935$ & 0.347 & F & 3.98 & 24.7 & 0.263 \\
\hline & Mix & 2 & 1.569 & $0.893-2.757$ & 0.117 & $\mathrm{~F}$ & 0.19 & 0.0 & 0.660 \\
\hline & African-American & 1 & 1.303 & $0.212-7.991$ & 0.775 & - & - & - & - \\
\hline & PB & 5 & 0.883 & $0.659-1.184$ & 0.407 & $\mathrm{~F}$ & 6.26 & 36.1 & 0.181 \\
\hline & $\mathrm{HB}$ & 7 & 0.886 & $0.555-1.413$ & 0.611 & $\mathrm{~F}$ & 7.49 & 19.9 & 0.278 \\
\hline & $\mathrm{HV}$ & 2 & 2.65 & $0.679-10.341$ & 0.161 & $\mathrm{~F}$ & 0.00 & 0.0 & 0.997 \\
\hline \multicolumn{10}{|l|}{ TNF-a-238G/A } \\
\hline \multirow[t]{5}{*}{ AA vs. GG } & Overall & 4 & 1.09 & $0.403-2.943$ & 0.866 & $\mathrm{~F}$ & 4.61 & 34.9 & 0.203 \\
\hline & Caucasia & 3 & 1.29 & $0.436-3.816$ & 0.645 & $\mathrm{~F}$ & 4.35 & 54.1 & 0.113 \\
\hline & African-American & 1 & 0.391 & $0.018-8.288$ & 0.547 & - & - & - & - \\
\hline & $\mathrm{HB}$ & 3 & 1.579 & $0.492-5.071$ & 0.442 & $\mathrm{~F}$ & 3.750 & 46.7 & 0.153 \\
\hline & PB & 1 & 0.344 & $0.036-3.310$ & 0.355 & - & - & - & - \\
\hline \multirow[t]{4}{*}{ AG vs. GG } & Overall & 5 & 1.07 & $0.680-1.683$ & 0.77 & $\mathrm{R}$ & 12.49 & 68.0 & 0.014 \\
\hline & Caucasia & 3 & 1.284 & $0.841-2.025$ & 0.282 & $\mathrm{R}$ & 5.99 & 66.6 & 0.050 \\
\hline & Asia & 1 & 0.431 & $0.200-0.931$ & 0.032 & - & - & - & - \\
\hline & African-American & 1 & 1.179 & $0.408-3.405$ & 0.706 & - & - & - & - \\
\hline
\end{tabular}


Table 3 Meta-analysis of the TNF-a gene polymorphisms on prostate cancer risk (Continued)

\begin{tabular}{|c|c|c|c|c|c|c|c|c|c|}
\hline & $\mathrm{HB}$ & 4 & 1.008 & $0.506-2.010$ & 0.981 & $\mathrm{R}$ & 11.3 & 73.4 & 0.01 \\
\hline & PB & 1 & 1.248 & $0.944-1.649$ & 0.12 & - & - & - & - \\
\hline \multirow[t]{6}{*}{$A A+A G$ vs. GG } & Overall & 5 & 1.06 & $0.713-1.575$ & 0.774 & $\mathrm{R}$ & 9.95 & 59.8 & 0.041 \\
\hline & Caucasia & 3 & 1.226 & $0.982-1.531$ & 0.072 & $\mathrm{~F}$ & 3.33 & 39.9 & 0.189 \\
\hline & Asia & 1 & 0.431 & $0.200-0.931$ & 0.032 & - & - & - & - \\
\hline & African-American & 1 & 0.983 & $0.351-2.752$ & 0.974 & - & - & - & - \\
\hline & $\mathrm{HB}$ & 4 & 0.984 & $0.535-1.808$ & 0.958 & $\mathrm{R}$ & 9.170 & 67.3 & 0.027 \\
\hline & PB & 1 & 1.221 & $0.926-1.610$ & 0.156 & - & - & - & - \\
\hline \multirow[t]{5}{*}{$A A$ vs. $G G+A G$} & Overall & 4 & 1.036 & $0.388-2.767$ & 0.943 & $\mathrm{~F}$ & 4.9 & 38.2 & 0.182 \\
\hline & Caucasia & 3 & 0.892 & $0.084-9.494$ & 0.925 & $\mathrm{R}$ & 4.63 & 56.8 & 0.099 \\
\hline & African-American & 1 & 0.386 & $0.018-8.161$ & 0.541 & - & - & - & - \\
\hline & $\mathrm{HB}$ & 3 & 1.468 & $0.467-4.615$ & 0.511 & $\mathrm{~F}$ & 4.050 & 50.6 & 0.132 \\
\hline & PB & 1 & 0.336 & $0.035-3.238$ & 0.346 & - & - & - & - \\
\hline
\end{tabular}

Ethnicity and different source of controls were significant factors for heterogeneity.

We also performed Galbraith plots analysis to identify the outliers that might contribute to the heterogeneity. The study of Oh et al. [16] was an outlier in the additive model AG vs. GG, while the studies of Oh et al. [16] and Sáenz-López et al. [14] were both outliers in the dominant model AA + AG vs. GG for TNF- $\alpha-308 \mathrm{G} / \mathrm{A}$ polymorphism (Figure 3). When these two studies were excluded from the analysis, the $\mathrm{I}^{2}$ values decreased obviously and the $\mathrm{P}_{\mathrm{Q}}$ values were greater than 0.10 in the overall populations (additive model: $\mathrm{P}_{\mathrm{Q}}=0.267, \mathrm{I}^{2}=$ 17.5\%; dominant model: $\mathrm{P}_{\mathrm{Q}}=0.295, \mathrm{I}^{2}=15.2 \%$ ), Caucasians (additive model: $\mathrm{P}_{\mathrm{Q}}=0.379, \mathrm{I}^{2}=5.9 \%$; dominant model: $\mathrm{P}_{\mathrm{Q}}=0.883, \mathrm{I}^{2}=0.0 \%$ ), and hospital-based studies (additive model: $\mathrm{P}_{\mathrm{Q}}=0.294, \mathrm{I}^{2}=18.4 \%$; dominant model: $\mathrm{P}_{\mathrm{Q}}=0.240, \mathrm{I}^{2}=25.9 \%$ ).

For the TNF- $\alpha-238 \mathrm{G} / \mathrm{A}$ polymorphism, substantial heterogeneities were observed between studies in the additive model AG vs. GG $(\mathrm{p}=0.014)$ and dominant model AA + AG vs. GG ( $\mathrm{p}=0.041)$ in the overall populations. We further employed subgroup analyses stratified by ethnicity and source of controls. However, heterogeneities were still observed among hospital-based studies in these two genetic models (Table 3). Therefore, ethnicity was considered to contribute to substantial heterogeneity.

\section{Sensitivity analysis}

A leave-one-out sensitivity analysis was performed to reflect the influence of the individual dataset to the pooled ORs. The results suggested that no single investigation significantly affected the pooled ORs (data not shown). When we excluded HWE-violating studies, the corresponding pooled ORs were not materially altered, indicating that the data in this meta-analysis are relatively stable and credible.

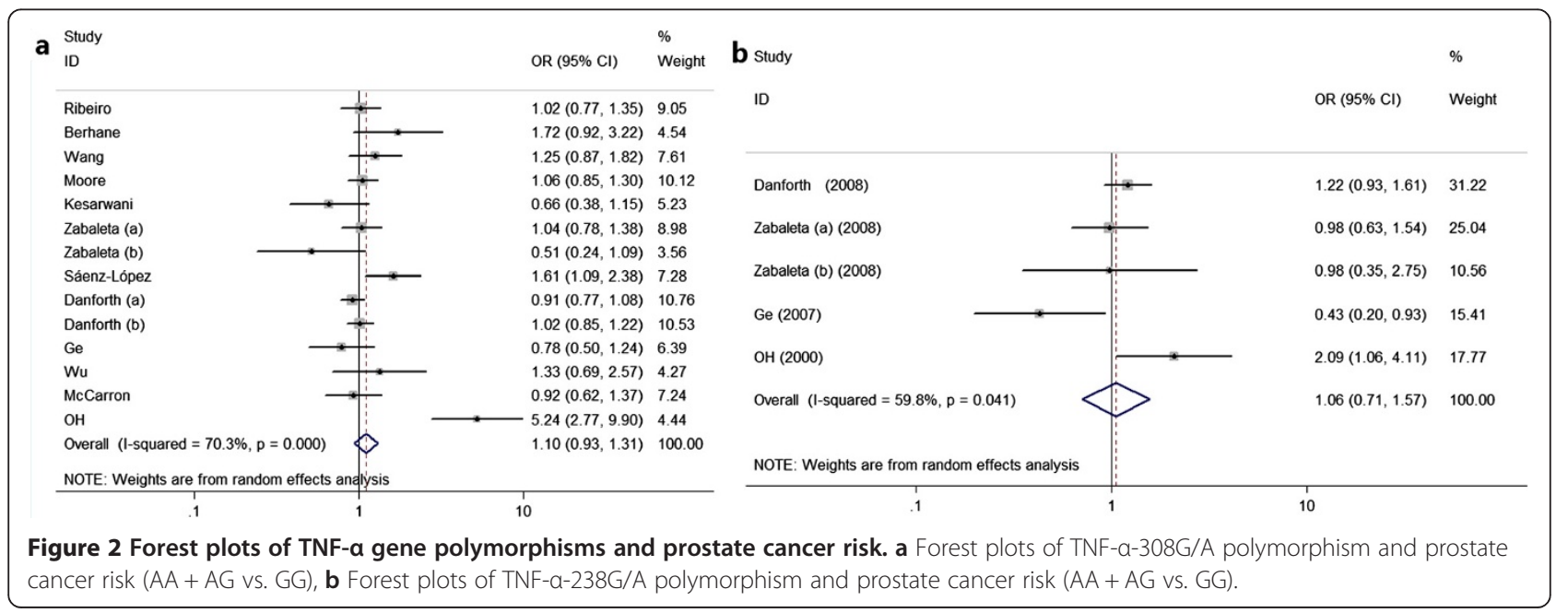



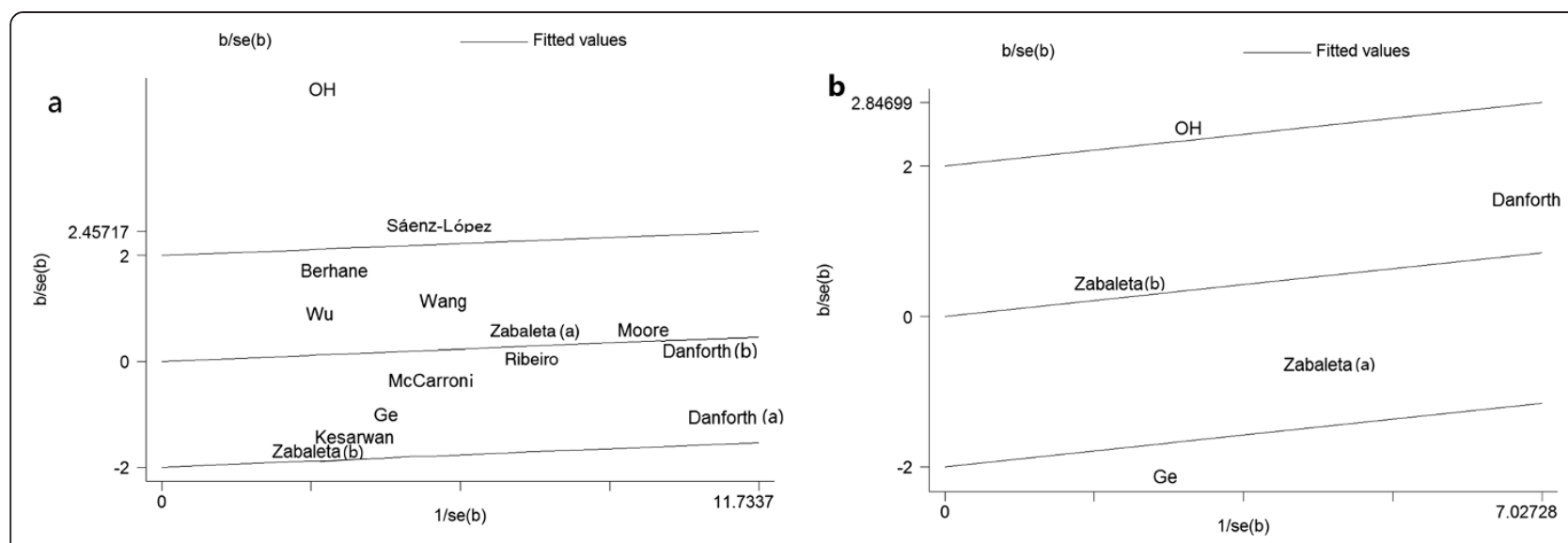

Figure 3 Galbraith plots of TNF-a-308G/A polymorphism and prostate cancer risk in different contrast models. a The studies of OH et al., Sáenz-López et al. were outliers in dominant models AA + AG vs. GG. b OH et al. was outlier in additive model AG vs. GG.

\section{Publication bias}

Begg's funnel plot and Egger's linear regression tests were created to estimate the publication bias risk in this metaanalysis. As shown in Figure 4, the shapes of the funnel plots did not show obvious asymmetry. In addition, the results of Egger's test also revealed the absence of publication bias in the TNF- $\alpha-308 \mathrm{G} / \mathrm{A}$ ( $\mathrm{P}=0.224$ for AA vs. GG; $\mathrm{P}=0.350$ for $\mathrm{AG}$ vs. GG; $\mathrm{P}=0.313$ for recessive model AA vs. $\mathrm{GG}+\mathrm{AG}$; and $\mathrm{P}=0.275$ for dominant model $\mathrm{AA}+\mathrm{AG}$ vs. GG) and TNF- $\alpha-238 \mathrm{G} / \mathrm{A}(\mathrm{P}=0.742$ for AA vs. GG; $\mathrm{P}=0.758$ for $\mathrm{AG}$ vs. $\mathrm{GG} ; \mathrm{P}=0.763$ for recessive model $\mathrm{AA}$ vs. GG + AG; and P $=0.629$ for dominant model AA + AG vs. GG) polymorphisms.

\section{Discussion}

TNF- $\alpha$ is a member of the TNF/TNFR cytokine superfamily, and is an intercellular communicating molecule involved in building transient or long-lasting multicellular structures [34]. It is also known to play critical and nonredundant roles in the innate and adaptive immune responses [35], including the response to tumours [36]. TNF- $\alpha$ has been directly and indirectly linked to neoplasia and is involved not only in maintenance and homeostasis of the immune system, inflammation, and host defence, but also in pathological processes such as chronic inflammation, autoimmunity, and malignant disease [35,37]. TNF- $\alpha$ expression is mostly regulated at the transcriptional level [38]. Promoter polymorphisms in the TNF- $\alpha$ gene related to the pro- and anti-inflammatory response could directly influence production of TNF- $\alpha$, thus causing inter-individual differences in immune responsiveness, which may influence the susceptibility of prostate cancer [39].

Two variations in the promoter region of the TNF- $\alpha$ gene, namely, TNF- $\alpha-308 \mathrm{G} / \mathrm{A}$ and TNF- $\alpha-238 \mathrm{G} / \mathrm{A}$, have been commonly studied. The $\mathrm{G}$ to $\mathrm{A}$ substitution at position -308 in the TNF-a promoter increases TNF- $\alpha$ transcription activity and the serum TNF- $\alpha$ level [6]. Indeed, the TNF-308A allele has been associated with malignant tumours such as gastric cancer, breast carcinoma, and hepatocellular cancer [40-42]. The functional significance of the rare TNF-238A allele is not yet clear, but Kaluza et al. reported that this allele caused a significant
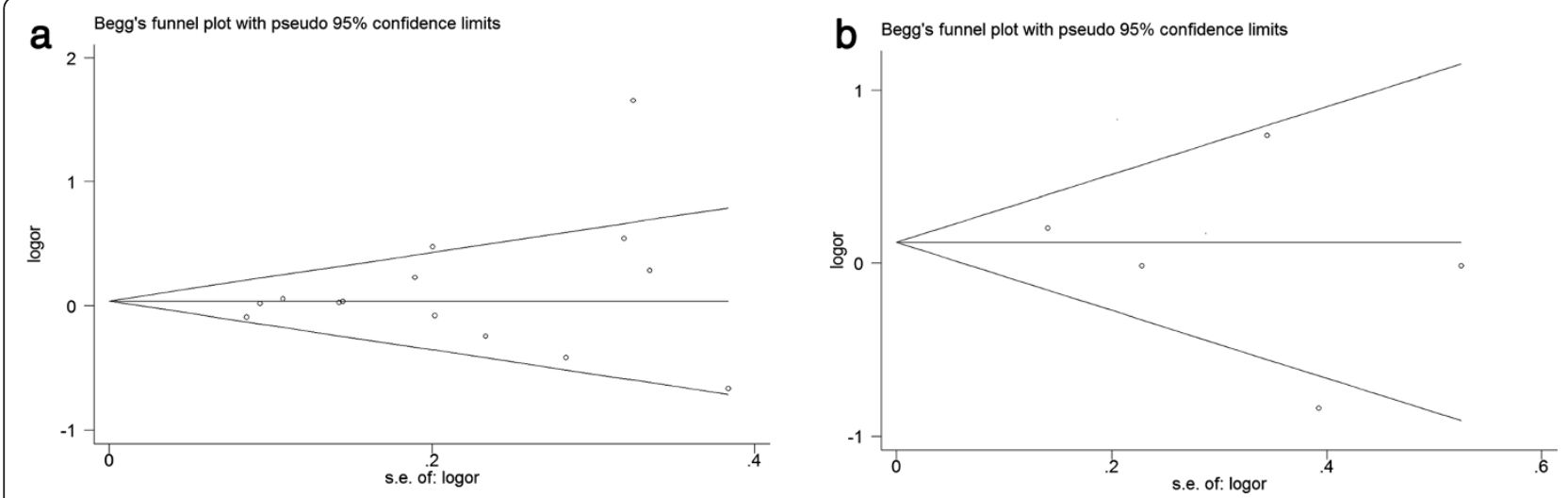

Figure 4 Funnel plot for the detection of the publication bias in this meta-analysis. a Funnel plot for contrast AA + AG VS. GG of TNF-a308G/A polymorphism in overall analysis; b Funnel plot for contrast AA + AG vs. GG of TNF-a-238G/A polymorphism in overall analysis. 
decreased in the transcription of the TNF- $\alpha$ gene in human $\mathrm{T}$ and $\mathrm{B}$ cells [43]. The allele has also been associated with certain autoimmune and infectious diseases [44,45]. Several studies have observed the association between prostate cancer risk and TNF- $\alpha$ promoter polymorphisms, and TNF- $\alpha$ 308G/A and/or TNF- $\alpha-238 \mathrm{G} / \mathrm{A}$ polymorphisms, but the results are controversial. These inconsistent results are possibly because of the small effect of the polymorphism on prostate cancer risk or the relatively low statistical power of the published studies. Meta-analysis could overcome these disadvantages because (1) it can investigate data for a large number of individuals; (2) it can estimate the effect of a genetic factor on disease risk; and (3) if a significant association is found, it can estimate whether the association is common among different backgrounds (such as population or age groups) [46-49]. Therefore, we performed a meta-analysis to comprehensively evaluate the association between TNF- $\alpha-308 \mathrm{G} / \mathrm{A}$ and/or TNF- $\alpha-238 \mathrm{G} / \mathrm{A}$ polymorphisms and prostate cancer risk.

Our meta-analysis summarized for the first time all the available data on the association between TNF- $\alpha$ 238G/A polymorphism and prostate cancer risk, including a total of five studies, involving 1,967 prostate cancer cases and 2,004 controls. Our results demonstrated that the TNF- $\alpha-238 \mathrm{G} / \mathrm{A}$ polymorphism was not significantly associated with prostate cancer risk not only in the overall population but also in the subgroup analyses stratified by ethnicity and source of controls.

With respect to TNF- $\alpha-308 \mathrm{G} / \mathrm{A}$ polymorphism, 14 studies including 5,757 prostate cancer cases and 6,137 controls were found in our meta-analysis. The data suggested no significant association between TNF- $\alpha-308 \mathrm{G} / \mathrm{A}$ polymorphism and prostate cancer risk in all genetic models in the overall populations, which is consistent with the previous findings made by Wang et al. [24] and Wang et al. [17]. However, in the subgroup analysis according to source of controls, significantly increased prostate cancer risk was found in the healthy volunteer studies but not in hospital-based and population-based studies. However, the result may be underpowered because the sample size the healthy volunteer studies in this analysis is relatively small, and controls in these studies may not always be truly representative of the general population. Therefore, a methodologically preferable design such as a representative population-based study is needed to avoid selection bias and to increase the statistical power.

For the TNF- $\alpha-308 \mathrm{G} / \mathrm{A}$ polymorphism, substantial heterogeneities between studies were observed in the additive model AG vs. GG $(\mathrm{p}<0.001)$ and dominant model AA + AG vs. GG $(p<0.001)$ in the overall populations. To explore the source of heterogeneity, we employed metaregression and subgroup analyses. Meta-regression analysis revealed no definite source of heterogeneity. Subgroup analyses by ethnicity showed that heterogeneity existed in
Caucasian subjects and hospital-based studies in the additive and dominant models. To further investigate the heterogeneity, Galbraith plot analysis was used to identify the outliers that might contribute to the heterogeneity, and two outliers were found. When they were excluded from the analysis, the $\mathrm{I}^{2}$ values decreased obviously and $\mathrm{P}_{\mathrm{Q}}$ values were greater than 0.10 in the overall populations and in Caucasians. In addition, excluding the two studies did not significantly affect the results in the different comparison models in the overall population and subgroup analyses. The results indicated that the two studies might be the major source of the heterogeneity for the 308G/A polymorphism.

Substantial heterogeneities between studies were observed in the additive and dominant models for the TNF$\alpha-238 \mathrm{G} / \mathrm{A}$ polymorphism in the Caucasian population and hospital-based studies. As only five studies on the association between TNF- $\alpha-238$ G/A polymorphism and prostate cancer risk were included in our meta-analysis, meta-regression analysis and Galbraith plots analysis were not performed; therefore, these results require further investigation.

This meta-analysis has some limitations that must be considered. First, the overall outcomes were based on individual unadjusted ORs, while a more precise estimation should be adjusted by confounding factors such as smoking status, age, and environmental factors. Second, the sample sizes in this analysis were not adequate, especially the African-American populations; therefore, more subjects of different ethnicities would be required to accurately clarify whether ethnicity has a biological influence on cancer susceptibility. Third, the controls were not consistently screened across the studies analysed. Therefore, the control groups may have different risks of developing prostate cancer. Fourth, as only certain published studies were included in our meta-analysis, publication bias is very likely to occur although it was not shown in the statistical test.

\section{Conclusions}

In conclusion, the present meta-analysis suggests that the TNF- $\alpha$-238/A polymorphism is unlikely to be a risk factor for prostate cancer, while the TNF- $\alpha-308$ G/A polymorphism may make a significant contribution to the risk of prostate cancer in healthy volunteers. However, to clarify the role of TNF- $\alpha-308 \mathrm{G} / \mathrm{A}$ and TNF- $\alpha-238 \mathrm{G} / \mathrm{A}$ polymorphism in prostate carcinogenesis, more studies with large samples are needed in the future.

\section{Abbreviations}

TNF-a: Tumor necrosis factor-alpha; SNPs: Single nucleotide polymorphisms; HWE: Hardy-Weinberg equilibrium; OR: Odds ratio; Cl: Confidence interval; PCR-RFLP PCR: Based restriction fragment length polymorphism; QC: Quality control.

\section{Competing interests}

The authors declare that they have no competing interests. 
Authors' contributions

All authors have read and approved the final files for this manuscript.

\section{Acknowledgements}

This work was not supported by any kind of fund.

Received: 18 December 2013 Accepted: 23 March 2014

Published: 25 March 2014

\section{References}

1. Siegel R, Naishadham D, Jemal A: Cancer statistics, 2013. CA: a cancer journal for clinicians 2013, 63:11-30

2. Witte JS: Prostate cancer genomics: towards a new understanding. Nature reviews Genetics 2009, 10:77-82.

3. Aronson KJ, Siemiatycki J, Dewar R, Gerin M: Occupational risk factors for prostate cancer: results from a case-control study in Montreal, Quebec Canada. American journal of epidemiology 1996, 143:363-373.

4. Hiatt RA, Armstrong MA, Klatsky AL, Sidney S: Alcohol consumption, smoking, and other risk factors and prostate cancer in a large health plan cohort in California (United States). Cancer causes \& control: CCC 1994, 5:66-72.

5. Lichtenstein P, Holm NV, Verkasalo PK, lliadou A, Kaprio J, Koskenvuo M, Pukkala E, Skytthe A, Hemminki K: Environmental and heritable factors in the causation of cancer-analyses of cohorts of twins from Sweden, Denmark, and Finland. The New England journal of medicine 2000, 343:78-85.

6. Kroeger KM, Carville KS, Abraham $\sqcup$ : The -308 tumor necrosis factor-alpha promoter polymorphism effects transcription. Molecular immunology 1997, 34:391-399.

7. Merchant JL: Inflammation, atrophy, gastric cancer: connecting the molecular dots. Gastroenterology 2005, 129:1079-1082.

8. Watts TH: TNF/TNFR family members in costimulation of T cell responses. Annual review of immunology 2005, 23:23-68.

9. Hoosein NM: Neuroendocrine and immune mediators in prostate cancer progression. Frontiers in bioscience: a journal and virtual library 1998, 3:D1274-D1279.

10. Fargion S, Valenti L, Dongiovanni P, Scaccabarozzi A, Fracanzani AL, Taioli E, Mattioli M, Sampietro M, Fiorelli G: Tumor necrosis factor alpha promoter polymorphisms influence the phenotypic expression of hereditary hemochromatosis. Blood 2001, 97:3707-3712.

11. Valenti L, Fracanzani AL, Dongiovanni P, Santorelli G, Branchi A, Taioli E, Fiorelli G Fargion S: Tumor necrosis factor alpha promoter polymorphisms and insulin resistance in nonalcoholic fatty liver disease. Gastroenterology 2002, 122:274-280

12. D'Alfonso S, Richiardi PM: A polymorphic variation in a putative regulation box of the TNFA promoter region. Immunogenetics 1994, 39:150-154.

13. Wilson AG, Symons JA, McDowell TL, McDevitt HO, Duff GW: Effects of a polymorphism in the human tumor necrosis factor alpha promoter on transcriptional activation. Proceedings of the National Academy of Sciences of the United States of America 1997, 94:3195-3199.

14. Saenz-Lopez P, Carretero R, Cozar JM, Romero JM, Canton J, Vilchez JR, Tallada M, Garrido F, Ruiz-Cabello F: Genetic polymorphisms of RANTES, IL1-A, MCP-1 and TNF-A genes in patients with prostate cancer. BMC cancer 2008, 8:382.

15. Danforth KN, Rodriguez C, Hayes RB, Sakoda LC, Huang WY, Yu K, Calle EE, Jacobs EJ, Chen BE, Andriole GL, Figueroa JD, Yeager M, Platz EA, Michaud DS, Chanock SJ, Thun MJ, Hsing AW: TNF polymorphisms and prostate cancer risk. The Prostate $2008,68: 400-407$.

16. Oh BR, Sasaki M, Perinchery G, Ryu SB, Park YI, Carroll P, Dahiya R: Frequent genotype changes at -308 , and 488 regions of the tumor necrosis factor-alpha (TNF-alpha) gene in patients with prostate cancer. The Journal of urology 2000, 163:1584-1587.

17. Wang J, Cao C, Luo H, Xiong S, Xu Y, Xiong W: Tumour necrosis factor alpha -308G/A polymorphism and risk of the four most frequent cancers: a meta-analysis. International journal of immunogenetics 2011, 38:311-320.

18. Thakkinstian A, McEvoy M, Minelli C, Gibson P, Hancox B, Duffy D, Thompson J, Hall I, Kaufman J, Leung TF, Helms PJ, Hakonarson H, Halpi E, Navon R, Attia J: Systematic review and meta-analysis of the association between \{beta\}2-adrenoceptor polymorphisms and asthma: a HuGE review. American journal of epidemiology 2005, 162:201-211.

19. Higgins JP, Thompson SG, Deeks JJ, Altman DG: Measuring inconsistency in meta-analyses. BMJ (Clinical research ed) 2003, 327:557-560.
20. Mantel N, Haenszel W: Statistical aspects of the analysis of data from retrospective studies of disease. Journal of the National Cancer Institute 1959 22:719-748.

21. DerSimonian R, Laird N: Meta-analysis in clinical trials. Controlled Clinical Trials 1986, 7:177-188.

22. Egger M, Davey Smith G, Schneider M, Minder C: Bias in meta-analysis detected by a simple, graphical test. BMJ (Clinical research ed) 1997, 315:629-634.

23. Duval S, Tweedie R: Trim and fill: A simple funnel-plot-based method of testing and adjusting for publication bias in meta-analysis. Biometrics 2000 56:455-463.

24. Mangyuan W, Zhenwei H, Jiaming L, Banghua L: TNF-a gene-308 G/A polymorphism and the risk of prostate cancer: A Meta-Analysis. Chin $J$ Evid-based Med 2012, 8:1030-1034.

25. Ribeiro R, Monteiro CP, Azevedo AS, Cunha VF, Ramanakumar AV, Fraga AM, Pina FM, Lopes CM, Medeiros RM, Franco EL: Performance of an adipokine pathway-based multilocus genetic risk score for prostate cancer risk prediction. PloS one 2012, 7:e39236.

26. Berhane N, Sobti RC, Melesse S, Mahdi SA, Kassu A: Significance of Tumor necrosis factor alpha-308 (G/A) gene polymorphism in the development of prostate cancer. Molecular biology reports 2012, 39:11125-11130.

27. Wang MH, Helzlsouer KJ, Smith MW, Hoffman-Bolton JA, Clipp SL, Grinberg V, De Marzo AM, Isaacs WB, Drake CG, Shugart YY, Platz EA: Association of IL10 and other immune response- and obesity-related genes with prostate cancer in CLUE II. The Prostate 2009, 69:874-885.

28. Moore SC, Leitzmann MF, Albanes D, Weinstein SJ, Snyder K, Virtamo J, Ahn J, Mayne ST, Yu H, Peters U, Gunter MJ: Adipokine genes and prostate cancer risk. International journal of cancer Journal international du cancer 2009, 124:869-876.

29. Kesarwani P, Mandhani A, Mittal RD: Polymorphisms in tumor necrosis factor-A gene and prostate cancer risk in North Indian cohort. The Journal of urology 2009, 182:2938-2943.

30. Zabaleta J, Lin HY, Sierra RA, Hall MC, Clark PE, Sartor OA, Hu JJ, Ochoa AC: Interactions of cytokine gene polymorphisms in prostate cancer risk. Carcinogenesis 2008, 29:573-578.

31. Ge J: Studies on the relationship between single nucleotide polymorphisms and susceptibility to Prostate cancer in Chinese population. Soochow University: Master's thesis; 2007. doi:10.7666/d.y1178232.

32. Wu HC, Chang CH, Chen HY, Tsai FJ, Tsai JJ, Chen WC: p53 gene codon 72 polymorphism but not tumor necrosis factor-alpha gene is associated with prostate cancer. Urologia internationalis 2004, 73:41-46.

33. McCarron SL, Edwards S, Evans PR, Gibbs R, Dearnaley DP, Dowe A, Southgate C, Easton DF, Eeles RA, Howell WM: Influence of cytokine gene polymorphisms on the development of prostate cancer. Cancer research 2002, 62:3369-3372.

34. Locksley RM, Killeen N, Lenardo MJ: The TNF and TNF receptor superfamilies: integrating mammalian biology. Cell 2001, 104:487-501.

35. Balkwill F: TNF-alpha in promotion and progression of cancer. Cancer metastasis reviews 2006, 25:409-416.

36. Dranoff G: Cytokines in cancer pathogenesis and cancer therapy. Nature reviews Cancer 2004, 4:11-22

37. Beutler B, Cerami A: The biology of cachectin/TNF-a primary mediator of the host response. Annual review of immunology 1989, 7:625-655.

38. Raabe T, Bukrinsky M, Currie RA: Relative contribution of transcription and translation to the induction of tumor necrosis factor-alpha by lipopolysaccharide. The Journal of biological chemistry 1998, 273:974-980.

39. Bidwell J, Keen L, Gallagher G, Kimberly R, Huizinga T, McDermott MF, Oksenberg J, McNicholl J, Pociot F, Hardt C, D'Alfonso S: Cytokine gene polymorphism in human disease: on-line databases. Genes and immunity 1999, 1:3-19.

40. Yang Y, Luo C, Feng R, Bi S: The TNF-alpha, IL-1B and IL-10 polymorphisms and risk for hepatocellular carcinoma: a meta-analysis. Journal of cancer research and clinical oncology 2011, 137:947-952.

41. Shen C, Sun H, Sun D, Xu L, Zhang X, Liu A, Jia X, Bai J, Chen F, Yu Y, Jin Y, Yu J, Fu S: Polymorphisms of tumor necrosis factor-alpha and breast cancer risk: a meta-analysis. Breast cancer research and treatment 2011, 126:763-770.

42. Lu PH, Tang Y, Li C, Shen W, Ji L, Guo YJ, Tao GQ: [Meta-analysis of association of tumor necrosis factor alpha-308 gene promoter polymorphism with gastric cancer]. Zhonghua yu fang yi xue za zhi [Chinese journal of preventive medicine] 2010, 44:209-214.

43. Kaluza W, Reuss E, Grossmann S, Hug R, Schopf RE, Galle PR, Maerker-Hermann E, Hoehler T: Different transcriptional activity and in vitro TNF-alpha production 
in psoriasis patients carrying the TNF-alpha 238A promoter polymorphism. The Journal of investigative dermatology 2000, 114:1180-1183.

44. Hohler T, Kruger A, Gerken G, Schneider PM, Meyer Zum Buschenefelde KH, Rittner C: A tumor necrosis factor-alpha (TNF-alpha) promoter polymorphism is associated with chronic hepatitis B infection. Clinical and experimental immunology 1998, 111:579-582.

45. Brinkman BM, Huizinga TW, Kurban SS, van der Velde EA, Schreuder GM, Hazes JM, Breedveld FC, Verweij CL: Tumour necrosis factor alpha gene polymorphisms in rheumatoid arthritis: association with susceptibility to, or severity of, disease? British journal of rheumatology 1997. 36:516-521.

46. Cheng D, Shi H, Zhang K, Yi L, Zhen G: RAD51 Gene 135G/C polymorphism and the risk of four types of common cancers: a meta-analysis. Diagnostic pathology 2014, 9:18.

47. Wang L, Cai S, Teng Z, Zhao X, Chen X, Bai X: Insulin therapy contributes to the increased risk of colorectal cancer in diabetes patients: a meta-analysis. Diagnostic pathology 2013, 8:180.

48. Yu L, Chen J: Association of MTHFR Ala222Val (rs1801133) polymorphism and breast cancer susceptibility: An update meta-analysis based on 51 research studies. Diagnostic pathology 2012, 7:171.

49. Fujisawa $T$, Ikegami $H$, Kawaguchi $Y$, Ogihara T: Meta-analysis of the association of Trp64Arg polymorphism of beta 3-adrenergic receptor gene with body mass index. The Journal of clinical endocrinology and metabolism 1998, 83:2441-2444.

doi:10.1186/1746-1596-9-74

Cite this article as: Ma et al:: Association between Tumor necrosis factoralpha gene polymorphisms and prostate cancer risk: a meta-analysis.

Diagnostic Pathology 2014 9:74.

\section{Submit your next manuscript to BioMed Central and take full advantage of:}

- Convenient online submission

- Thorough peer review

- No space constraints or color figure charges

- Immediate publication on acceptance

- Inclusion in PubMed, CAS, Scopus and Google Scholar

- Research which is freely available for redistribution 